\title{
Mechanisms of ATP release in pain: role of pannexin and connexin channels
}

\author{
Manuel F. Muñoz ${ }^{1}$ Theanne N. Griffith ${ }^{1} \cdot$ Jorge E. Contreras ${ }^{1}$ (I)
}

Received: 4 June 2021 / Accepted: 18 October 2021 / Published online: 18 November 2021

(C) The Author(s) 2021

\begin{abstract}
Pain is a physiological response to bodily damage and serves as a warning of potential threat. Pain can also transform from an acute response to noxious stimuli to a chronic condition with notable emotional and psychological components that requires treatment. Indeed, the management of chronic pain is currently an important unmet societal need. Several reports have implicated the release of the neurotransmitter adenosine triphosphate (ATP) and subsequent activation of purinergic receptors in distinct pain etiologies. Purinergic receptors are broadly expressed in peripheral neurons and the spinal cord; thus, purinergic signaling in sensory neurons or in spinal circuits may be critical for pain processing. Nevertheless, an outstanding question remains: what are the mechanisms of ATP release that initiate nociceptive signaling? Connexin and pannexin channels are established conduits of ATP release and have been suggested to play important roles in a variety of pathologies, including several models of pain. As such, these large-pore channels represent a new and exciting putative pharmacological target for pain treatment. Herein, we will review the current evidence for a role of connexin and pannexin channels in ATP release during nociceptive signaling, such as neuropathic and inflammatory pain. Collectively, these studies provide compelling evidence for an important role of connexins and pannexins in pain processing.
\end{abstract}

Keywords ATP release $\cdot$ Connexins $\cdot$ Pannexins $\cdot$ Acute pain $\cdot$ Chronic pain

Manuel F. Muñoz Camus graduated with a Ph.D (maximum distinction) in Biological Sciences mention Physiological Sciences from the Pontifical Catholic University of Chile (PUC), Chile. He studied the role of ionotropic and metabotropic glutamate receptors in astrocytic $\mathrm{Ca}^{2+}$ signaling in the context of neurovascular coupling during his Ph.D thesis in the laboratory of Dr. Xavier Figueroa (Department of Physiology, PUC). Currently, he is a postdoctoral fellow in the laboratory of Dr. Jorge Contreras at the University of California, Davis, USA. He is focusing on the role of connexin-formed hemichannels and pannexin-based channels in cardiovascular diseases.

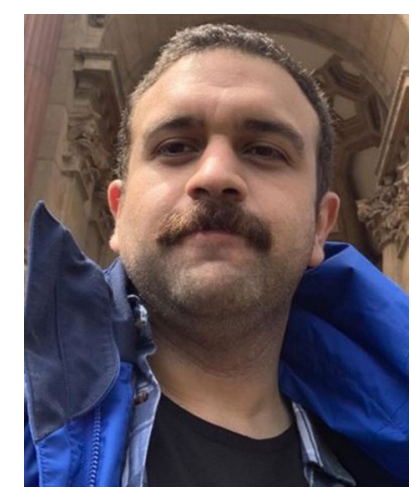

Jorge E. Contreras

jecontrer@ucdavis.edu

Manuel F. Muñoz

mmunozcamus@ucdavis.edu

Theanne N. Griffith

tgriffith@ucdavis.edu

1 Department of Physiology and Membrane Biology, School of Medicine, University of California, Davis, USA

\section{Introduction}

Pain is an essential physiological response, warning of current or possible tissue damage, and is also modulated by psychological, emotional, and societal components [1]. Within this definition lies an array of pain etiologies, which can be broadly classified as either acute or chronic. Acute pain, also referred to as nociceptive pain, is defined as a sensation evoked by noxious stimuli that activates pain-sensing peripheral sensory neurons. These peripheral nociceptors transmit 
acute pain signals via myelinated A-delta- and unmyelinated $\mathrm{C}$-afferents [2,3]. Nociceptive pain can originate in most tissues, including musculoskeletal, visceral, and skin [4-6]. On the other hand, chronic pain is described as the manifestation of an injury, disorder, or disease that can last for months to years [3]. Two common forms of chronic pain include neuropathic and inflammatory pain. Neuropathic pain is defined as pain caused by a lesion or disease of the somatosensory nervous system [7]. A plethora of disorders, or their respective treatment plans, result in peripheral neuropathic pain, including AIDS, diabetes, and cancer [8], and approximately $\sim 53 \%$ of spinal cord injury patients develop some form of neuropathic pain [9]. In addition to peripheral neuropathy, central neuropathic pain can occur as a result of damage to the central nervous system (CNS), including stroke, encephalitis, and demyelinating disease like multiple sclerosis [10]. Inflammatory pain, such as that caused by diseases like arthritis, involves tissue damage that results in the recruitment of immune cells and subsequent release of proinflammatory substances, including cytokines and adenosine 5 '-triphosphate (ATP). Both neuropathic and inflammatory pain are associated with an elevated sensitivity to innocuous stimuli (such as warm water or changing clothes), as well as hypersensitivity to noxious stimuli, referred to as allodynia and hyperalgesia, respectively [11]. There is abundant evidence that extracellular ATP and other nucleotides have an important role in pain signaling both in the periphery and in the CNS. Nevertheless, important questions remain, including the mechanisms through which ATP is released to activate nociceptive purinergic signaling pathways.

In 1972, ATP was proposed to be an extracellular signaling molecule present in the peripheral nervous system (PNS) and the CNS [12]. Since then, 7 subtypes of ionotropic purinergic receptors have been identified (P2X1-7) [13]. Additionally, 8 subtypes of metabotropic receptors have also been characterized (P2Y1, P2Y2, P2Y4, P2Y6, $\mathrm{P} 2 \mathrm{Y} 11, \mathrm{P} 2 \mathrm{Y} 12$, $\mathrm{P} 2 \mathrm{Y} 13$, and $\mathrm{P} 2 \mathrm{Y} 14)$ [13]. All $\mathrm{P} 2 \mathrm{X}$ isoforms have been detected in the PNS [13], whereas only transcripts of $\mathrm{P} 2 \mathrm{Y} 1, \mathrm{P} 2 \mathrm{Y} 2, \mathrm{P} 2 \mathrm{Y} 4$, and $\mathrm{P} 2 \mathrm{Y} 6$ have been observed in sensory neurons of the dorsal root, trigeminal, and nodose ganglia [13-15]. Nearly half of spinal cord dorsal horn neurons use ATP as a fast excitatory neurotransmitter, where it activates $\mathrm{P} 2 \mathrm{X}$ receptors present in laminae I-III of the spinal cord, the termination zone of presynaptic nociceptive afferents [16]. Much research has been devoted to establishing the subtype specific contributions of purinergic receptors to different forms of pain signaling. In particular, activation of the homomeric P2X3 and $\mathrm{P} 2 \mathrm{X} 2 / 3$ receptors in sensory neurons have been associated with acute pain behaviors [17-19]. For example, blocking $\mathrm{P} 2 \mathrm{X} 3$ receptors with the selective $\mathrm{P} 2 \mathrm{X} 3$ receptor antagonist A-317491 prevented acute muscle hyperalgesia, but had no effect on chronic-muscle pain [18]. Conversely, the activation and upregulation of $\mathrm{P} 2 \mathrm{X} 4$ receptors on glial cells (i.e., microglia) are linked to the pathogenesis and development of neuropathic pain and mechanical allodynia, thus representing a pathway promoting the development of chronic pain [20-22]. Similarly, P2X7 receptors have been primarily associated with neuropathic and chronic inflammatory pain, showing a selective upregulation in human dorsal root ganglia, glial cells, and immune cells (i.e., monocytes and lymphocytes) [3, 23, 24].

Several reviews have recently addressed in detail the roles purinergic receptors play in both acute and chronic pain [25-27]. Conversely, less studied are the mechanisms of ATP release that initiate purinergic signaling during pain. Pannexins and connexin channels have been proposed to be critical for ATP release involved in the development of pain, representing possible therapeutical targets for analgesic drugs [28, 29]. Herein, we will describe the emerging role of these large-pore channels as conduits of ATP release during nociceptive signaling (Fig. 1).

\section{ATP signaling in pain}

ATP was first explicitly hypothesized to initiate nociceptive signaling via activation of purinergic receptors on sensory nerve terminals nearly 30 years ago [30]. Since then, a plethora of studies have used both pharmacological and genetic approaches to delineate the subtype-specific role of purinergic receptors in diverse pain etiologies. Various P2Y metabotropic receptors are expressed in spinal cord astrocytes, microglia, and small nociceptive cells, as well as large-diameter mechanosensory neurons [31]. Increased expression of both $\mathrm{P} 2 \mathrm{Y} 6$ and $\mathrm{P} 2 \mathrm{Y} 11$ has been observed following spinal nerve ligation, and pharmacologically blocking these receptors in the spinal cord was antiallodynic [32]. Novel antagonists of P2Y14 receptors were reported to ameliorate neuropathic pain in rats subjected to sciatic nerve injury; however, additional studies are required to support this finding [33]. Upregulation of $\mathrm{P} 2 \mathrm{Y} 12$ receptor mRNA and protein in activated spinal microglia has been observed in different rodent models of nerve injury and both pharmacological inhibition and genetic deletion of $\mathrm{P} 2 \mathrm{Y} 12$ receptors reduced tactile allodynia following nerve injury [34, 35]. Consistent with this, a P2Y12 agonist intrathecally administered to naive animals produced pain behaviors [34], suggesting that P2Y12 signaling in spinal microglia contributes to neuropathic pain. P2Y12 has also been shown to be regulated in satellite glia cells, which encase dorsal root ganglia (DRG) and trigeminal ganglia (TG) neuron soma, following chronic constriction injury (CCI) in rats to mediate both tactile and thermal hyperalgesia [36]. Finally, P2Y2 receptors are also expressed in satellite glia cells of the TG and inhibition of 


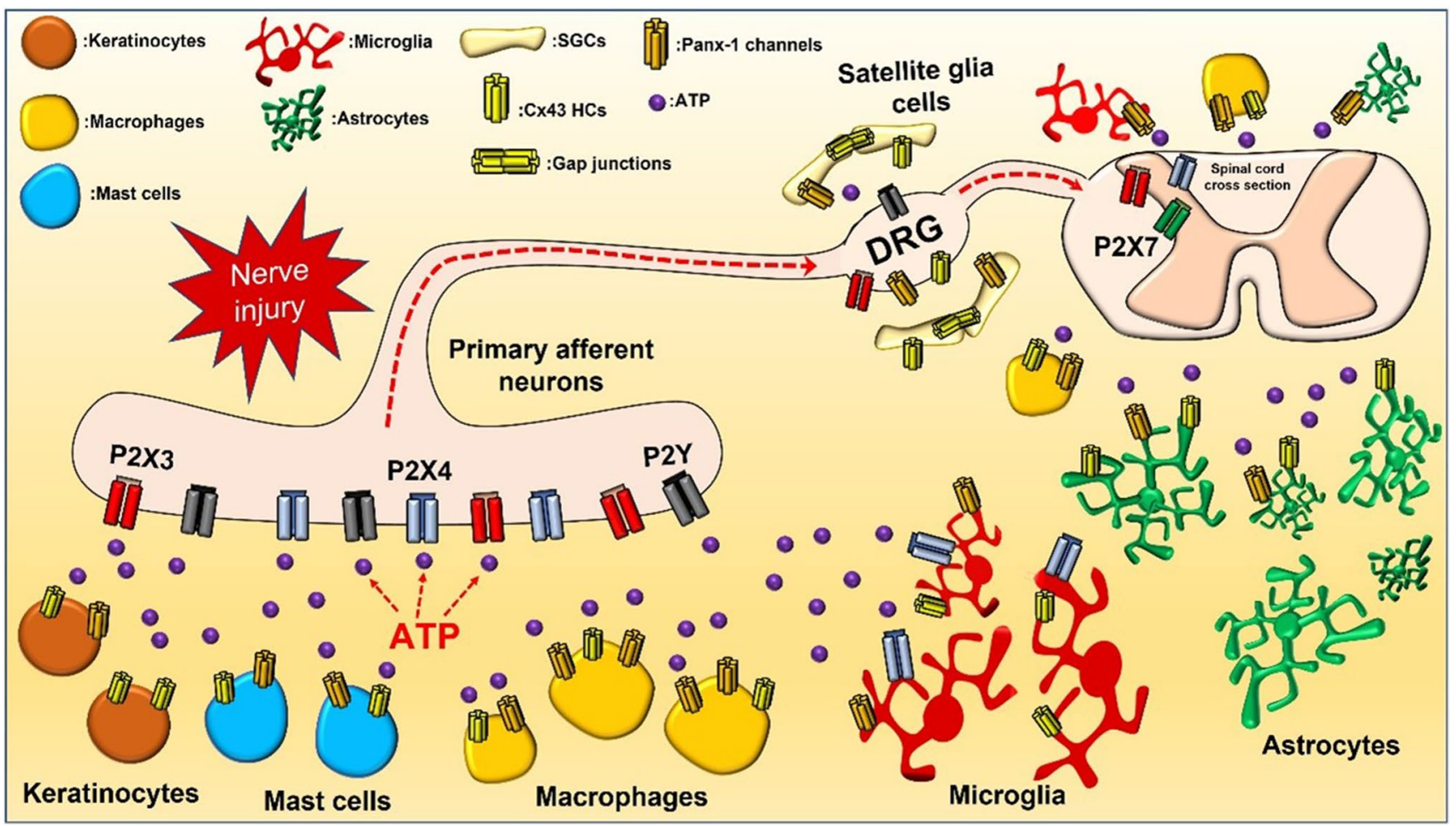

Fig. 1 A schematic diagram of the cell types and possible sources of ATP release during pain. ATP is released from a variety of cells, including epithelial cells (keratinocytes), immune cells (mast cells, macrophages), glial cells (microglial, astrocyte, and satellite glial cells), and neurons. Pannexin and connexin channels are shown in the cell types where they have been found to play a role in pain. Similarly, P2X or P2Y receptors are displayed in sensory nerves, DRG, and spinal cord, where they can transmit acute and/or chronic pain signals

$[46,47]$. Use of the competitive $\mathrm{P} 2 \mathrm{X} 7$ receptor antagonist, A-740003, resulted in blockage of IL- $1 \beta$ release from THP-1 cells, a monocyte-like cell line, and attenuation of tactile allodynia in a concentration-dependent manner in two models of neuropathic pain [48]. In a CFA rat model of arthritis, co-administration of the selective P2X7 receptor inhibitor, oxidized ATP (OxATP), significantly decreased chronic inflammatory pain compared to CFA administration alone [49]. Consistent with this notion, daily administration of the non-selective P2X7 antagonist pyridoxalphosphate-6-azophenyl-2[prime],4[prime]disulfonic acid (PPADS) led to a decrease in observable pain behaviors, reversed mechanical allodynia, reduced expression of proinflammatory cytokines, and decreased neuronal nitric oxide synthase (nNOS) and inducible nitric oxide synthase (iNOS) immunoreactivity in a CCI mouse model [50]. Furthermore, dexmedetomidine, selective $\alpha 2$-adrenoceptor agonist used for sedation, was proposed to attenuate neuropathic pain induced by CCI through inhibition of spinal P2X7 receptor expression [51]. P2X7 receptors have been described to be intimately involved in microglial activation and cancer-induced allodynia, in which the use of siRNA of $\mathrm{P} 2 \mathrm{X} 7$ reduced these painrelated effects [52]. Collectively, these studies support a by high concentrations of ATP following nerve injury 
role for $\mathrm{P} 2 \mathrm{X} 7$ receptors in the spinal cord as early mediators of cellular damage during chronic inflammatory pain. Nevertheless, important contributions of other P2X isoforms have also been identified.

Indeed, P2X4 may have an exciting new role as a therapeutic target for neuropathic pain in humans with herpes zoster or Guillain-Barré syndrome (GBS). A novel P2X4 antagonist, NP-1815-PX, exhibited anti-allodynic effects in a mouse model of herpetic pain and reduced mechanical allodynia after spinal nerve transection [53]. These analgesic effects may result from decreased mRNA levels of P2X4 receptors in spinal microglial cells, which were observed after inoculation with the herpes virus [53]. Nevertheless, the specificity of this new compound for P2X4 receptors remains to be verified by other groups. In experimental autoimmune neuritis, an animal model of the GBS subtype demyelinating polyradiculoneuropathy, P2X4 receptor expression increased in microglial cells present in the lumbar dorsal horn, but not in astrocytes [54]. Based on immunohistochemistry, the authors suggested that the accumulation of P2X4 receptors in the lumbar dorsal horn may contribute to mechanical allodynia in this model [54]. Consistently, similar results were obtained after GBS animals were treated with the antidepressant paroxetine, which is also a potent antagonist of $\mathrm{P} 2 \mathrm{X} 4$, resulting in attenuated mechanical allodynia [55]. Blocking monoclonal antibodies injected intrathecally at the L4-L6 spinal level in mice also induced analgesia in a mouse model of sciatic nerve ligation [56]. In line with this, global P2X $\mathrm{X}^{-/-}$mice did not develop mechanical hypersensitivity after peripheral nerve injury, and also had impaired brain-derived neurotrophic factor (BDNF) release [57]. A different study, however, showed chronic inflammatory and neuropathic pain signaling were intact in $\mathrm{P} 2 \mathrm{X}^{-/-}$mice, which suggests a pain-etiology specific role for this isoform [58]. Collectively, these results highlight the important role of $\mathrm{P} 2 \mathrm{X}$ receptors in various pain signaling pathways and demonstrate that purinergic signaling represents an exciting therapeutic target for pain treatment. Conversely, the mechanisms mediating ATP release during pain remain poorly defined.

\section{Sources of ATP release in pain}

Several cell types are poised to release ATP to orchestrate the complex signaling pathways that underlie nociception (Fig. 1). Sensory neurons play a fundamental role in nociception by transmitting pain signals from the periphery to the CNS. Primary afferents also release ATP onto lamina II spinal cord neurons to activate post-synaptic $\mathrm{P} 2 \mathrm{X}$ receptors and elicit fast excitatory postsynaptic currents (EPSCs), which can be blocked by antagonists, such as PPADS and suramin [59]. Work with mice harboring genetic deletion of the ATP vesicular transport protein, vesicular nucleotide transporter (VNUT), suggests a role for vesicle-mediated ATP release during different forms of pain. VNUT, whose gene name is $S L C 17 A 9$, was originally cloned from mouse and human and was postulated to play a critical role in ATP transport in ATP-releasing cells [60]. It was shown that siRNA-mediated knockdown of SLC17A9 in PC12 cells, a pheochromocytoma cell line, diminished ATP exocytosis, suggesting its participation in ATP release from secretory vesicles [60]. VNUTs have been functionally linked to ATP exocytosis in a variety of physiological processes, including lysosomal ATP accumulation, cell survival, neutrophil migration, astrocyte signaling, neuro-glial communication, and microglial-mediated neuropathic pain [61-69]. Interestingly, the use of clodronate, a selective VNUT inhibitor, attenuated chronic inflammatory and neuropathic tactile pain in wildtype mice, but not in $\mathrm{VNUT}^{-/-}$animals, with $\mathrm{VNUT}^{-/-}$mice also showing reduced mechanical hyperalgesia at baseline compared to controls [65]. Clodronate treatment decreased ATP release, and reduced expression of inflammatory markers, IL-6 release, and edema, supporting the role of VNUT mediating chronic neuropathic pain [65]. Consistent with this, spinal dorsal horn neurons from $\mathrm{VNUT}^{-/-}$mice did not show increased ATP release following nerve injury, which was observed in control animals, providing evidence that pain-induced exocytotic ATP release in the spinal cord is dependent on VNUT [63]. There was no difference, however, between $\mathrm{VNUT}^{-/-}$mice and controls in acute nocifensive behaviors, suggesting this pathway is specifically activated during chronic pain conditions. Furthermore, tactile allodynia was still present when VNUT was selectively deleted in astrocytes, microglia, and primary sensory neurons after peripheral nerve injury [63]. This suggests that vesicular ATP release does not trigger pain signaling in all cell types involved in pain, opening the possibility for non-vesicular ATP release mechanisms, such as those mediated by molecule permeable channels like connexin- 43 (Cx43) and pannexin-1 (Panx-1) hemichannels.

Epidermal keratinocytes have an intimate physical interaction with intraepidermal nociceptive nerve fibers and are thus poised to modulate pain signaling [70,71]. These cells express several transient receptor potential (TRP) channels that respond to a variety of environmental signals, including noxious stimuli [72-74]. Cultured human epidermal keratinocytes stimulated with capsaicin, the spicy component of chili peppers, responded with increased $\mathrm{Ca}^{2+}$ signaling [75]. Topical application of capsaicin to the mouse hind paw induced ATP release from keratinocytes, along with the expression of the neuronal activation marker, c-fos, in laminae I and II of the dorsal horn [76]. Keratinocytes are capable of non-vesicular ATP release via connexin hemichannels following air stimulation, a model of mechanical force, thus demonstrating the potential role for these cells to initiate 
purinergic signaling in primary afferents. ATP release from keratinocytes has also been shown to induce $\mathrm{Ca}^{2+}$ waves in dorsal root ganglion (DRG) neurons, leading to pain behaviors [77-80]. Importantly, it has been shown that mechanical stimulation of primary normal human epidermal keratinocytes (NHEKs) causes an increase in $\mathrm{Ca}^{2+}$ signaling in DRG neurons, which was diminished in the presence of ATPdegrading enzyme apyrase, as well as $\mathrm{P} 2 \mathrm{X}$ receptor blockers suramin and PPADS, suggesting that ATP release from keratinocytes onto DRG neurons may represent an important pathway of nociceptive transduction during pain [78].

Mast cells are granulated hematopoietic cells that are part of the immune and neuroimmune systems and play a crucial role as first responders during several painful pathologies $[81,82]$. When these cells are activated and consequently degranulated, they secrete several pro-inflammatory molecules locally at the site of the injury, such as ATP, TNF- $\alpha$, and interleukins that can amplify nociceptor activation and pain signaling. This occurs via direct activation of sensory axons, as well as microglia and other mast cells [82-84]. Macrophages are another important cell class involved in pain signaling that release ATP, as well as cytokines and TNF- $\alpha$. These pro-inflammatory signals are detected by nociceptors and contribute to peripheral neuropathic pain pathogenesis [85-88]. Indeed, administration of macrophage depleting agents suppresses thermal hyperalgesia and tactile allodynia induced by the partial SNL in male mice [89].

Finally, glial cells are one of the most important nonneuronal cell types that release ATP and are involved in pain signaling pathways. Astrocytes are thought to be critical targets for the late maintenance phase of neuropathic pain after nerve injury or tissue damage [90], due to their activation by glutamate, ATP, calcitonin gene-related peptide (CGRP), or substance P [91], which results in astrocytic release of pro-inflammatory cytokines [92]. Nerve injury produces astrogliosis and ATP release from astrocytes in the injured area, which subsequently leads to neuroinflammation [93-95]. Furthermore, optogenetic activation of spinal astrocytes evokes mechanical allodynia, thermal hyperalgesia, and pain hypersensitivity via the release of ATP [96]. As with astrocytes in the CNS, satellite glial cells (SGCs) surround the soma of DRG neurons where they are proposed to help control the local cellular environment. SGCs are also important for neuronal health and serve a protective function, much like brain astrocytes. Bidirectional SGC-to nociceptor signaling via ATP release may modulate afferent firing [97, 98], suggesting a role in nociception. Lastly, microglial cells are defined as macrophages of the CNS that undergo an activation process of proliferation [99]. In response to nerve injury in the PNS, infiltrating monocytes differentiate into microglia-like cells [97], upregulating P2X4 receptors [100]. Interestingly, pharmacological blockage of spinal $\mathrm{P} 2 \mathrm{X} 4$ receptors reversed tactile allodynia induced by nerve injury, which increased P2X4 expression only in microglial cells, but not in neurons or astrocytic cells [20]. Additionally, microglia have also been proposed to induce ATP release via connexin hemichannels and pannexin channels in the context of physiological neuron-astrocyte-microglial crosstalk [101]. This remains to be examined, however, in the context of pain.

Following ATP release, its availability is tightly regulated by ectonucleotidases, ectoenzymes that regulate extracellular ATP concentrations and, therefore, are closely involved in the temporal kinetics and amplitude of purinergic receptor activation [102]. Ectonucleotidases breakdown ATP into adenosine-5'-diphosphate (ADP), adenosine monophosphate (AMP), and adenosine [103]. They include the nucleoside triphosphate diphosphohydrolase (NTPDase), nucleotide pyrophosphatase/phosphodiesterase (NPP), ecto-50-nucleotidase/CD73, tissue-nonspecific alkaline phosphatase (TNAP), and prostatic acid phosphatase (PAP) families, as well as other phosphatases such as adenosine deaminase (ADA) and purine nucleoside phosphorylase (PNP) [102]. Recently, ectonucleotidases have also been linked to nociceptive signaling. For example, it was reported that sciatic nerve transection produced decreased mRNA levels of the ectonucleotidase PAP in rat DRG, which is consistent with the antiallodynic effect of intrathecal injection of PAP protein in a spared nerve injury [104]. Similarly, a study using a mouse model of resiniferatoxin (RTX)-induced neuropathic pain showed that exogenous PAP treatment via intraperitoneal injection attenuated mechanical allodynia in a dosedependent manner [105]. This is in line with several other studies demonstrating the anti-nociceptive effects of PAP and the ectonucleotidase CD73 in models of chronic inflammatory or neuropathic pain [106-108]. Thus, mounting evidence suggests ectonucleotidase-mediated control of ATP availability could play an important role in both acute and chronic purinergic nociceptive signaling.

\section{Biology of connexins and pannexins and its role in ATP release}

In humans, there are 21 different connexin (Cxs) isoforms that are found throughout the body. These proteins form hemichannels or gap junction channels that mediate intercellular molecular communication in a diverse array of processes. These include various aspects of development and physiology, as well as responses to injury and inflammation [109]. In a cell, six connexin proteins oligomerize to form a hemichannel that is sorted to the plasma membrane. The docking of two hemichannels at the plasma membrane from adjacent cells leads to the formation of gap junction channels (GJCs). GJCs constitute intercellular channels that allow the cytoplasmic passage of second messengers 
such as $\mathrm{Ca}^{2+}$ and inositol 1,4,5-trisphosphate $\left(\mathrm{IP}_{3}\right)$ between neighboring cells [110-112]. Undocked hemichannels can also open at the plasma membrane and play paracrine or autocrine roles by mediating communication between the extracellular and intracellular space via the release of transmitter molecules such as $\mathrm{NAD}^{+}$, glutamate, prostaglandins, and ATP [113-116].

An interesting demonstration for ATP permeability via $\mathrm{Cx} 43$-formed hemichannels combined single-channel recordings along with the luciferace/luciferine bioluminescence assay of ATP release [117]. The authors showed that ATP release occurs in parallel with hemichannel opening in the C6 rat glioma cell line. ATP release was not observed when hemichannels were closed or in the presence of hemichannel blockers such as carbenoxolone (CBX) and 5-nitro-2-(3-phenylpropylamino) benzoic acid (NPPB) [117]. ATP release via connexin hemichannels has been proposed to have both physiological and pathological roles. It has been shown that after a cerebral ischemia and reperfusion model of oxygen and glucose deprivation, primary astrocyte cultures have increased extracellular ATP levels and ethidium uptake, which was prevented in the presence of Cx43 blocking peptides, Gap19 and Gap26, suggesting that Cx43 hemichannel mediates the release of ATP after brain ischemia [118]. Interestingly, photostimulation of Hensen's inner ear cell cultures with caged-IP ${ }_{3}$ induces the release of ATP, an effect that was not observed in $\mathrm{Cx} 26^{-/-}$or $\mathrm{Cx} 30^{-/-}$cell cultures, providing evidence that ATP is also released from connexin-hemichannels in sensory hair cell regions [119]. Consistent with this notion, Cx26 and Cx30 missense mutations that cause hearing-impairments, deafness, and skin disorders significantly alter hemichannelmediated ATP release [120-122]. Interestingly, Cx43, Cx30, and $\mathrm{Cx} 26$ are expressed in astrocytes, with $\mathrm{Cx} 43$ being the most predominant subtype [123, 124]. Cultured microglia cells displayed increased expression levels of Cx29, Cx32, $\mathrm{Cx} 36$, and $\mathrm{Cx} 46$ in proinflammatory conditions induced by lipopolysaccharides (LPS), TNF- $\alpha$, or brain injury [125]. Mast cells have been shown to express $\mathrm{Cx} 43$ protein, while macrophages were found to express both $\mathrm{Cx} 43$ and $\mathrm{Cx} 37$ [126]. Activated SGCs surrounding trigeminal ganglia neurons also have high levels of $\mathrm{Cx} 43$ expression after lower first molar pulp inflammation, which was inhibited by the blocking peptide of Cx43, Gap26 [127]. RNA sequencing analysis showed that $\mathrm{Cx} 43, \mathrm{Cx} 32, \mathrm{Cx} 30, \mathrm{Cx} 26, \mathrm{Cx} 45$, and $\mathrm{Cx} 36$ are predominantly expressed in the trigeminal ganglia and DRG of adult mice [128, 129]. Thus, there is a growing body of evidence indicating that cells involved in pain signaling and modulation express various types of connexin proteins, which can potentially serve as an important purinergic pathway for nociceptive signaling.

In 2000, Sergey Lukyanov's group discovered pannexin proteins, which were highly similar to invertebrate innexins
[130]. In the human genome, 3 genes encode for pannexins: Panx-1, Panx-2, and Panx-3 [131]. Pannexins are considered integral membrane proteins, with cytoplasmic aminoand carboxy-terminals, four transmembrane segments, and two extracellular loops. This topology is grossly similar to that observed for connexin proteins [132]; however, pannexin channels do not form GJCs, likely due to extracellular glycosylation. They do form plasma membrane channels that allow for the passage of substances up to $1 \mathrm{kDa}$ in size [133-135]. Recent high-resolution structures show that the Panx-1 channel is formed by oligomerization of seven Panx-1 proteins [136-138]. Pannexins were extensively detected in the brain, gastrointestinal tract, spinal cord, lung, kidney, thyroid, skeletal muscle, heart, and endocrine organs [133]. Panx-1 is expressed in a variety of cell types, including lymphocytes, astrocytes, neurons, microglia, adipocytes, airway epithelia, and blood vessels [139-143]. Conversely, Panx-2 is preferentially expressed in the CNS and Panx-3 is expressed in skeletal muscle and the epidermal layer of skin $[144,145]$. The most well-studied pannexin is Panx1 , which has been shown to play essential roles in several physiological processes such as maturation of excitatory synapses [146], bone differentiation [147], and skin development [148]. Panx-1 channels are also linked to various pathophysiological roles including neuronal death [149], hemodynamic response to hypoxia [150], and neuroinflammation [151]. While many reports have established that Panx-1 channels are permeable to ATP, it has been suggested that only certain open channel conformations will permit the permeation of large molecules [152]. Currently, available high-resolution structures of open Panx-1 channels are compatible with chloride permeability, but it is unlikely that their pore, with the dimensions reported, can permit passage of large molecules like ATP. Nevertheless, it is likely that Panx-1 channels adopt various open conformations, as they display multiple channel conductances that range from 50 to $500 \mathrm{pS}$ [152-155]. It is probable that only the larger unitary conductance $(\sim 500 \mathrm{pS})$ can permeate ATP and other metabolites, whereas smaller channel conductances are primarily permeating chloride ions, as has been suggested [135, 152]. However, Panx-1 channels in which the C-terminus is deleted by caspases displayed ATP permeability with channel conductances ranging from 50 to $100 \mathrm{pS}$ [155]. This has been recently corroborated by studies using purified Panx-1 channels in proteoliposomes, which upon activation with caspase-3 became permeable to large molecules (up to $1 \mathrm{kDa}$ ) including ATP and glutamate [156]. Importantly, most of the cells described previously as pain mediators such keratinocytes, mast cells, macrophages, astrocytes, microglia, and SGCs have been reported to release ATP via pannexin-based channels [157-162]. Collectively, this evidence indicates that connexin and pannexin proteins may represent a putative therapeutical target to dampen ATP release from 
cells, which could be important for attenuating the generation and development of different forms of pain.

\section{Connexin 43 hemichannels and gap junctions in nerve injury-induced pain}

Among the different connexin subtypes, $\mathrm{Cx} 43$ is by far the most well studied in various pain models. It is ubiquitously expressed, and therefore is found in many cellular types that are involved in pain signaling. This includes glial cells, such as astrocytes of the spinal cord dorsal horn [163], and SGCs in the trigeminal ganglion [164]. Several reports have suggested a particular role for ATP release from Cx 43 hemichannels in pain evoked by nerve injury. Mechanical allodynia and heat hyperalgesia were significantly reduced in knockout $\mathrm{Cx} 30 / \mathrm{Cx} 43$ mice compared to controls during a two-month period in a weight drop spinal cord injury model. Astrogliosis was also reduced in these genetically modified mice after 1 week and 1-month post-injury when compared to wild-type controls. Interestingly, deletion of Cx30 alone does not prevent mechanical allodynia and hyperalgesia [163]. Using immunofluorescence analysis, a subsequent study found that following nerve injury $\mathrm{Cx} 43$ co-localized with the reactive astrocytic marker, glial fibrillary acidic protein (GFAP), but not with the neuronal marker NeuN, or the microglial/macrophage marker $\mathrm{CX} 3 \mathrm{C}$ chemokine receptor 1 (CX3CR1) [165]. Cx43 protein expression was increased in the spinal cord dorsal horn at 10 and 21 days following nerve injury and, interestingly, intrathecal injection of Cx 43 blocking peptides, ${ }^{43} \mathrm{Gap} 26$ or ${ }^{37,43} \mathrm{Gap} 27$ significantly reduced mechanical allodynia in this model [165]. The authors also showed that $\mathrm{Cx} 43$ hemichannels promote the release of the proinflammatory chemokine CXCL1 in response to spinal injection of TNF- $\alpha$. This consequently enhanced excitatory synaptic transmission in spinal cord neurons, thereby promoting mechanical allodynia for $>48 \mathrm{~h}$. This is further evidence that $\mathrm{Cx} 43$-based hemichannels could represent an important pathway for pain signaling.

Adding further complexity to the participation of connexin proteins in pain, pharmacological studies have suggested not only the involvement of the connexin-based hemichannels in the development of pain, but also the role of intercellular gap junction channels. It was reported that intrathecal administration of CBX, also used as a nonspecific gap junction decoupler, reverted the generation of mechanical allodynia and thermal hyperalgesia in a sciatic inflammatory neuropathy model, as well as in the classic model of CCI in adult male rats [166]. Similarly, L4 DRG neurons treated with CFA or animals with CCI presented a higher number of coupled neurons (defined as two or more neuronal soma located within $1 \mathrm{~mm}$ of each other showing synchronous $\mathrm{Ca}^{2+}$ GCaMP-coded signals) compared with the vehicle using in vivo DRG $\mathrm{Ca}^{2+}$ imaging [167]. Notably, Cx43 expression is increased after CFA and CCI only in SGCs of the DRG. Consistently, the specific deletion of $\mathrm{Cx} 43$ in SGCs showed an attenuation of $\mathrm{Ca}^{2+}$ coupled cells and less mechanical hyperalgesia induced by CFA in comparison to control animals, suggesting a critical role of Cx43 SGCs in pain. Systemic administration of CBX also induced a significant decrease in coupled neurons and pain hypersensitivity, similarly with results performed in $\mathrm{Cx} 43$ KO mice. This suggests that Cx43 in SGCs contributes to neuronal coupling via intercellular communication and are fundamental for the development of mechanical hyperalgesia and allodynia [167]. Interestingly, it has been reported that following injection of the dye Lucifer Yellow in mice with sciatic nerve neuritis, SGCs showed an increased number of coupled cells in relation to control conditions. Furthermore, based on electron microscopy data, SGCs from animals with nerve injury presented ultrastructural changes compared to wild-type animals, expressing an increased number of gap junction plaques and bridges between sheaths surrounding neurons, supporting the finding of an enhanced gap junction coupling signaling after nerve injury [168]. In other models of inflammatory pain, intraperitoneal administration of CBX reduced tactile hypersensitivity induced by injection of CFA in the submandibular skin of mice [169]. Increasing doses of CBX inhibited evident symptoms of neuropathic pain, such as mechanical and heat hypersensitivity. Furthermore, 30-60 min after topical application of CBX to the spinal cord, the number of action potentials evoked during extracellular recordings from dorsal horn neurons was reduced [170]. Although Cx43 gap junction channels do not directly leak ATP to the extracellular environments, they seem to be important modulators of chronic pain likely via the passage of the ions and signaling molecules [171, 172]. Indeed, intercellular $\mathrm{Ca}^{2+}$ waves that are spread via astrocytic $\mathrm{Cx} 43$ gap junction channels [173] can contribute to the release of ATP from astrocytes onto sensory neurons, which consequently may trigger the activation of purinergic receptors on nociceptor terminals [163]. Overall, the findings suggest that Cx43mediated cell-cell coupling might have a significant effect on the hyperexcitability of sensory neurons in chronic pain. Yet, CBX and genetic deletion of Cx43 also affect activity of Cx43 hemichannels; thus, a role for hemichannels cannot be ruled out in these models.

Connexin proteins have also been linked to chemotherapy-induced neuropathic pain [174, 175]. In fact, animals treated with bortezomib, a chemotherapy drug that induces peripheral neuropathy, exhibit increased expression of $\mathrm{Cx} 43$ in spinal astrocytes compared to those treated with vehicle [175]. Co-treatment with CBX reduced alterations in mechanical sensitivity, which lead to the hypothesis that upregulation of $\mathrm{Cx} 43$ by treatment with bortezomib might pathologically enhance hemichannel and GJC activity [176]. 
This finding is also replicated with oxaliplatin treatment, another chemotherapy drug that often produces peripheral neuropathy. Oxaliplatin treatment increased protein expression of GFAP and $\mathrm{Cx} 43$ in spinal cord astrocytes at day 7 post-administration, whereas $\mathrm{Cx} 32$ and $\mathrm{Cx} 36$ protein expression were unmodified compared to vehicle-treated animals [175]. Application of CBX produced a decrease in mechanical hypersensitivity triggered by oxaliplatin [175]. Consistent with the pathological role described above for augmented cell-to-cell coupling in SGCs, in vitro studies showed that oxaliplatin induced an increased incidence of cell coupling in cultured SGCs compared with those in control conditions [177]. While it is clear that chemotherapy drugs affect $\mathrm{Cx} 43$ expression, the specific role that gap junctions and hemichannels play in neuropathic pain induced by chemotherapy treatment needs to be explored further using more specific pharmacological and genetic approaches.

\section{Critical role of Panx-1-based channels in neuropathic pain}

Pannexin channels, particularly those formed by Panx-1 proteins, have been implicated in neuropathic pain and several other pathophysiological conditions [161]. Low doses of CBX $(10,25$, and $50 \mathrm{mg} / \mathrm{kg})$, generally used as a Panx-1 channel blocker [178], were reported to efficiently reverse the hypersensitivity induced by CFA [169], compared with saline-treated animals. Consistent with this, Panx-1 null mice did not develop tactile hypersensitivity in an orofacial pain model compared with wild-type animals. Spray and colleagues showed that submandibular injection of CFA induced an increase in mRNA levels of Panx-1, IL-1, caspase-1, and increased ATP release in the trigeminal ganglia. All of these effects were completely abolished in animals with a global knockout of Panx-1. This was replicated in mice with Panx-1 deletion only in GFAPpositive glia cells, highlighting the importance of Panx-1 channels in the regulation of pain responses [179].

Interestingly, it has been reported that pain hypersensitivity evoked by peripheral nerve injury depends on diurnal oscillations of glucocorticoid release from the adrenal glands [180]. In this study, the authors established that temporal elevations in glucocorticoid levels increase the release of ATP in the spinal cord, which could have a direct effect on the activation of $\mathrm{P} 2 \mathrm{Y} 12$ purinergic receptors present on the cell membrane of microglial cells. Four-hour treatment with corticosterone induced an increase in ATP release from primary cultures of astrocytes compared to vehicle-treated astrocytes, which was reduced by pannexin channel inhibitors, but not connexin channel inhibitors [180]. For instance, astrocytes incubated with $100 \mu \mathrm{M}{ }^{10} \mathrm{Panx}-1$ or astrocytes transfected with a siRNA against pannexin-1 has significantly decreased ATP release induced by corticosterone. Therefore, the authors suggest that corticosterone-induced ATP release occurs through a mechanism that depends on Panx-1 channel opening, leading to the activation of $\mathrm{P} 2 \mathrm{Y} 12$ receptors on microglia to generate mechanical allodynia [180].

In other models of neuropathic pain, such as L5/L6 SNL, similar results have been obtained. For example, nerve injury produces an increase in Panx-1 expression in DRG at 5, 10, and 21 days after the SNL surgery. Similarly, intrathecal injection of CBX and ${ }^{10} \mathrm{Panx}-1$ reduced pain hypersensitivity, in line with results using siRNA knockdown of Panx-1, in which tactile and pressure withdrawal thresholds were decreased in SNL-treated rats 3 weeks post-surgery [181]. Similar results have shown that intrathecal administration of the Panx-1 blockers ${ }^{10}$ Panx-1, carbenoxolone, and probenecid depressed the spinal C-reflex wind-up activity and mechanical hyperalgesia in neuropathic rats 10 days after nerve injury [182]. Again, this supports the notion that Panx-1 channels are mediators of ATP release in neuropathic pain syndromes. In other pathologies, such as cortical spreading depression (CSD), which is purported to be the cause of migraine aura and headaches, inhibition of Panx-1 channels with CBX suppressed trigeminal pain fiber activation, degranulation of mast cells, and pain as measured using a mouse grimace scale [183]. Additionally, Panx-1 channels have been suggested to be targets of opiates. The withdrawal behavior evoked by morphine normally induces long-term facilitation in neurons located at lamina I and II of the spinal dorsal horn, generating analgesia. However, genetic deletion of Panx-1 in microglia abolished the spinal facilitation and ameliorated the withdrawal response. The investigators suggested that during withdrawal, Panx-1 channels are activated, which induces ATP release from microglial cells [160]. Taken together, this large body of evidence indicates that Panx-1 channels represent a critical pathway to induce the release of ATP from different inflammatory cells that contribute to the pain signaling.

\section{Future directions}

During pain, a plethora of cells, epithelial cells, glia, and immune cells mediate the release of ATP to activate purinergic receptors on sensory terminals and the subsequent transmission of nociceptive signals to the spinal cord and brain. Evidence suggests that during different pain states, connexin and pannexin channels might serve as critical conduits for ATP release, as well as other pro-inflammatory molecules. Nevertheless, the role for these channels in most pain animal models is mainly supported by pharmacological approaches. These include selective and non-selective blockers such as the mimetic blocking peptide ${ }^{10} \mathrm{Panx}-1$, probenecid, and, in numerous cases, CBX. While the selectivity of mimetic blocking peptides is to some extent reliable, non-selective 
blockers such as CBX in the absence of other indistinct treatments make results more complex to interpret. For instance, there are other ATP-permeable channels such as the calcium homeostasis modulators (CALHMs) or volume-regulated anion channels (named SWELL1 or LRRC8A), which share pharmacological properties with pannexin and connexin channels. Importantly, a putative role for these channels in pain also remains unexplored. Thus, future studies are needed using more specific pharmacological tools and cell type-specific knockout rodent models for connexin and pannexin genes. These studies will help us to unequivocally determine the potential therapeutical role of pannexins and connexin proteins for treating pain, which is a broad and complicated condition among patients around the world, representing a difficult yet important public health challenge.

Author contribution MFM, TNG, and JEC wrote the manuscript. All authors reviewed and approved the final draft.

Funding This research was supported by the New Jersey Commission for Brain Injury Research (CBIR19IRG014 to J.E. Contreras).

Data availability The datasets analyzed during the current study are available from the corresponding author on reasonable request.

Code availability No applicable.

\section{Declarations}

Ethics approval No applicable.

Consent to participate No applicable.

Consent for publication No applicable.

Conflict of interest The authors declare no competing interests.

Open Access This article is licensed under a Creative Commons Attribution 4.0 International License, which permits use, sharing, adaptation, distribution and reproduction in any medium or format, as long as you give appropriate credit to the original author(s) and the source, provide a link to the Creative Commons licence, and indicate if changes were made. The images or other third party material in this article are included in the article's Creative Commons licence, unless indicated otherwise in a credit line to the material. If material is not included in the article's Creative Commons licence and your intended use is not permitted by statutory regulation or exceeds the permitted use, you will need to obtain permission directly from the copyright holder. To view a copy of this licence, visit http://creativecommons.org/licenses/by/4.0/.

\section{References}

1. Raja SN, Carr DB, Cohen M et al (2020) The revised International Association for the Study of Pain definition of pain: concepts, challenges, and compromises. Pain 161:1976-1982
2. Millan MJ (1999) The induction of pain: an integrative review. Prog Neurobiol 57(1):1-164

3. Toulme E, Tsuda M, Khakh BS (2021) Chapter 10 On the role of ATP-gated $\mathrm{P} 2 \mathrm{X}$ receptors in acute, inflammatory and neuropathic pain. $1-12$.

4. Loeser JD, Treede RD (2008) The Kyoto protocol of IASP Basic Pain Terminology. Pain 137(3):473-477

5. Bryce TN, Biering-Sørensen F, Finnerup NB et al (2012) International Spinal Cord Injury Pain Classification: part I. Background and description Spinal Cord 50:413-417

6. Widerström-Noga E, Biering-Sørensen F, Bryce TN et al (2014) The international spinal cord injury pain basic data set (version 2.0). Spinal Cord 52:282-286

7. Jensen TS, Baron R, Haanpää M, Kalso E, Loeser JD, Rice ASC, Treede RD (2011) A new definition of neuropathic pain. Pain 152(10):2204-2205

8. Schaible HG (2007) Peripheral and central mechanisms of pain generation. Handb Exp Pharmacol 177:3-28

9. Burke D, Fullen BM, Stokes D, Lennon O (2017) Neuropathic pain prevalence following spinal cord injury: a systematic review and meta-analysis. Eur J Pain 21(1):29-44

10. Watson JC, Sandroni P (2016) Central neuropathic pain syndromes. Mayo Clin Proc 91:372-385

11. Prescott SA, Ratté S (2017) Somatosensation and pain. Conn's Translational. Neuroscience 23:517-539

12. Burnstock G (1972) Purinergic nerves. Pharmacol Rev 24(3):509-581

13. Burnstock G, Sawynok J (2015) Adenosine triphosphate and adenosine receptors and pain. Pharmacol of Pain 14:303-326

14. Ruan HZ, Burnstock G (2003) Localisation of P2Y1 and P2Y4 receptors in dorsal root, nodose and trigeminal ganglia of the rat. Histochem Cell Biol 120(5):415-426

15. Burnstock G (2007) Physiology and pathophysiology of purinergic neurotransmission. Physiol Rev 87(2):659-797

16. Jo YH, Schlichter R (1999) Synaptic corelease of ATP and GABA in cultured spinal neurons. Nat Neurosci 2:241-245

17. Cockayne DA, Hamilton SG, Zhu QM, Dunn PM, Zhong Y, Novakovic S, Malmberg AB et al (2000) Urinary bladder hyporeflexia and reduced pain-related behaviour in P2X3deficient mice. Nature 407(6807):1011-1015

18. Jorge CO, de Azambuja G, Gomes BB et al (2020) P2X3 receptors contribute to transition from acute to chronic muscle pain. Purinergic Signal 16:403-414

19. Jarvis MF (2021) Geoffery Burnstock's influence on the evolution of P2X3 receptor pharmacology. Purinergic Signal 17:33-39

20. Tsuda M, Shigemoto-Mogami Y, Koizumi S et al (2003) P2X4 receptors induced in spinal microglia gate tactile allodynia after nerve injury. Nature 424:778-783

21. Stokes L, Layhadi JA, Bibic L et al (2017) P2X4 receptor function in the nervous system and current breakthroughs in pharmacology. Front Pharmacol 8:1-15

22. Khir NAM, Noh ASM, Shafin N, Ismail CAN (2021) Contribution of P2X4 receptor in pain associated with rheumatoid arthritis: a review. Purinergic Signal 17:201-213

23. Chessell IP, Hatcher JP, Bountra C et al (2005) Disruption of the $\mathrm{P} 2 \mathrm{X} 7$ purinoceptor gene abolishes chronic inflammatory and neuropathic pain. Pain 114:386-396

24. Luchting B, Heyn J, Woehrle T et al (2016) Differential expression of P2X7 receptor and IL-1 $\beta$ in nociceptive and neuropathic pain. J Neuroinflammation 13:1-9

25. Burnstock G (2016) Purinergic mechanisms and pain. Adv Pharmacol 2016(75):91-137

26. Jacobson KA, Giancotti LA, Lauro F et al (2020) Treatment of chronic neuropathic pain: Purine receptor modulation. Pain $161: 1425-1441$ 
27. Luongo L, Guida F, Maione S, Jacobson KA, Salvemini D (2021) Adenosine metabotropic receptors in chronic pain management. Front Pharmacol 12:1-4

28. Jeon YH, Youn DH (2015) Spinal gap junction channels in neuropathic pain. Korean J Pain 28:231-235

29. Morioka N, Nakamura Y, Zhang FF et al (2019) Role of connexins in chronic pain and their potential as therapeutic targets for next-generation analgesics. Biol Pharm Bull 42:857-866

30. Burnstock G (1996) A unifying purinergic hypothesis for the initiation of pain. Lancet 347(9015):1604-1605

31. Gerevich Z, Illes P (2004) P2Y receptors and pain transmission. Purinergic Signal 1:3-10

32. Barragán-Iglesias P, Pineda-Farias JB, Cervantes-Durán C et al (2014) Role of spinal P2Y6 and P2Y11 receptors in neuropathic pain in rats: possible involvement of glial cells. Mol Pain 10:1-11

33. Mufti F, Jung YH, Giancotti LA et al (2020) P2Y14 Receptor antagonists reverse chronic neuropathic pain in a mouse model. ACS Med Chem Lett 11:1281-1286

34. Kobayashi K, Yamanaka H, Fukuoka T et al (2008) P2Y12 receptor upregulation in activated microglia is a gateway of p38 signaling and neuropathic pain. J Neurosci 28:2892-2902

35. Tozaki-Saitoh H, Tsuda M, Miyata H, Ueda K, Kohsaka S, Inoue $\mathrm{K}$ (2008) P2Y12 receptors in spinal microglia are required for neuropathic pain after peripheral nerve injury. J Neurosci 28(19):4949-4956

36. Zou L, Yu K, Fan Y et al (2019) The inhibition by Guanfu Base A of neuropathic pain mediated by P2Y 12 receptor in dorsal root ganglia. ACS Chem Neurosci 10:1318-1325

37. Magni G, Merli D, Verderio C, Abbracchio MP, Ceruti S (2015) $\mathrm{P} 2 \mathrm{Y} 2$ receptor antagonists as anti-allodynic agents in acute and sub-chronic trigeminal sensitization: role of satellite glial cells. Glia 63(7):1256-1269

38. Inoue K (2021) Nociceptive signaling of P2X receptors in chronic pain states. Purinergic Signal 17:41-47

39. Burnstock G (2006) Purinergic P2 receptors as targets for novel analgesics. Pharmacol Ther 110:433-454

40. Collo G, North RA, Kawashima E et al (1996) Cloning of $\mathrm{P} 2 \mathrm{X} 5$ and $\mathrm{P} 2 \mathrm{X} 6$ receptors and the distribution and properties of an extended family of ATP-gated ion channels. J Neurosci 16:2495-2507

41. Rae MG, Rowan EG, Kennedy C (1998) Pharmacological properties of $\mathrm{P} 2 \mathrm{X} 3$-receptors present in neurones of the rat dorsal root ganglia. Br J Pharmacol 124:176-180

42. Ueno S, Tsuda M, Iwanaga T, Inoue K (1999) Cell type-specific ATP-activated responses in rat dorsal root ganglion neurons. $\mathrm{Br}$ J Pharmacol 126:429-436

43. Teixeira JM, Bobinski F, Parada CA, et al (2017) P2X3 and $\mathrm{P} 2 \mathrm{X} 2 / 3$ receptors play a crucial role in articular hyperalgesia development through inflammatory mechanisms in the knee joint experimental synovitis. 6174-6186.

44. Deiteren A, van der Linden L, de Wit A, Ceuleers H, Buckinx R, Timmermans JP, Moreels TG, Pelckmans PA, De Man JG, De Winter BY (2015) P2X3 receptors mediate visceral hypersensitivity during acute chemically-induced colitis and in the postinflammatory phase via different mechanisms of sensitization. PLoS ONE 10(4):1-17

45. Ding S, Zhu L, Tian Y, Zhu T, Huang X, Zhang X (2017) P2X3 receptor involvement in endometriosis pain via ERK signaling pathway. PLoS ONE 12(9):e0184647

46. Wang X, Arcuino G, Takano T et al (2004) P2X7 receptor inhibition improves recovery after spinal cord injury. Nat Med 10:821-827

47. Di Virgilio F (2007) Liaisons dangereuses: P2X7 and the inflammasome. Trends Pharmacol Sci 28:465-472

48. Honore P, Donnelly-roberts D, Namovic MT, et al (2006) A-740003 [N-(1-\{[(Cyanoimino)(5-quinolinylamino) methyl] amino -2,2-dimethylpropyl)-2-(3,4-dimethoxyphenyl)acetamide], a novel and selective $\mathrm{p} 2 \times 7$ receptor antagonist, dosedependently reduces neuropathic pain in the Rat319:1376-1385.

49. Dell'Antonio G, Quattrini A, Cin ED, Fulgenzi A, Ferrero ME (2002) Relief of inflammatory pain in rats by local use of the selective P2X7 ATP receptor inhibitor, oxidized ATP. Arthritis Rheum 46(12):3378-3385

50. Martucci C, Trovato AE, Costa B, Borsani E, Franchi S, Magnaghi V, Panerai AE, Rodella LF, Valsecchi AE, Sacerdote P, Colleoni M (2008) The purinergic antagonist PPADS reduces pain related behaviours and interleukin-1 beta, interleukin-6, iNOS and nNOS overproduction in central and peripheral nervous system after peripheral neuropathy in mice. Pain 137(1):81-95

51. Lin JP, Chen CQ, Huang LE et al (2018) Dexmedetomidine attenuates neuropathic pain by inhibiting P2X7R Expression and erk phosphorylation in Rats. Exp Neurobiol 27:267-276

52. Yang Y, Li H, Li TT et al (2015) Delayed activation of spinal microglia contributes to the maintenance of bone cancer pain in female Wistar rats via P2X7 receptor and IL-18. J Neurosci 35:7950-7963

53. Matsumura Y, Yamashita T, Sasaki A et al (2016) A novel P2X4 receptor-selective antagonist produces anti-allodynic effect in a mouse model of herpetic pain. Sci Rep 6:1-11

54. Zhang Z, Zhang ZY, Fauser U, Schluesener HJ (2008) Mechanical allodynia and spinal up-regulation of $\mathrm{P} 2 \mathrm{X} 4$ receptor in experimental autoimmune neuritis rats. Neuroscience 152:495-501

55. Imai T, Nakata E, Inoue K (2012) Inhibition of P2X4 receptor on spinal microglia attenuates mechanical allodynia in experimental autoimmune neuritis rats. Pain Res 27:27-36

56. Williams WA, Linley JE, Jones CA et al (2019) Antibodies binding the head domain of P2X4 inhibit channel function and reverse neuropathic pain. Pain 160:1989-2003

57. Ulmann L, Hatcher JP, Hughes JP et al (2008) Up-regulation of $\mathrm{P} 2 \mathrm{X} 4$ receptors in spinal microglia after peripheral nerve injury mediates BDNF release and neuropathic pain. J Neurosci 28:11263-11268

58. Tsuda M, Kuboyama K, Inoue T et al (2009) Behavioral phenotypes of mice lacking purinergic $\mathrm{P} 2 \mathrm{X} 4$ receptors in acute and chronic pain assays. Mol Pain 5:1-7

59. Bardoni R (1997) ATP P(2X) receptors mediate fast synaptic transmission in the dorsal horn of the rat spinal cord. J Neurosci 17:5297-5304

60. Sawada K, Echigo N, Juge N et al (2008) Identification of a vesicular nucleotide transporter 105:15-18

61. Shinozaki Y et al (2014) Microglia trigger astrocyte-mediated neuroprotection via purinergic gliotransmission. Sci Rep 4:4329

62. Cao Q, Zhao K, Zhong XZ, Zou Y, Yu H, Huang P, Xu TL, Dong XP (2014) SLC17A9 protein functions as a lysosomal ATP transporter and regulates cell viability. J Biol Chem 289(33):23189-23199

63. Masuda T, Ozono Y, Mikuriya S et al (2016) Dorsal horn neurons release extracellular ATP in a VNUT-dependent manner that underlies neuropathic pain. Nat Commun 7:1-11

64. Harada Y, Kato Y, Miyaji T et al (2018) cro Vesicular nucleotide transporter mediates ATP release and migration in neutrophils. J Biol Chem 293:3770-3779

65. Kato Y, Hiasa M, Ichikawa R, Hasuzawa N, Kadowaki A, Iwatsuki K, Shima K, Endo Y, Kitahara Y, Inoue T, Nomura M, Omote H, Moriyama Y, Miyaji T (2017) Identification of a vesicular ATP release inhibitor for the treatment of neuropathic and inflammatory pain. Proc Natl Acad Sci U S A 114(31):E6297-E6305

66. Kinoshita M, Hirayama Y, Fujishita K et al (2018) EBioMedicine Anti-Depressant Fluoxetine Reveals its Therapeutic Effect Via Astrocytes. EBioMedicine 32:72-83 
67. Miras-Portugal MT, Menéndez-méndez A, Gómez-villafuertes R (2019) Physiopathological role of the vesicular nucleotide transporter ( VNUT ) in the central nervous system: relevance of the vesicular nucleotide release as a potential therapeutic target. 13:1-15.

68. Tsuda M (2019) Microglia-mediated regulation of neuropathic pain: molecular and cellular mechanisms. Biol Pharm Bull 42(12):1959-1968

69. Hasuzawa N, Moriyama S, Moriyama Y, Nomura M (2020) BBA - biomembranes physiopathological roles of vesicular nucleotide transporter (VNUT), an essential component for vesicular ATP release. BBA - Biomembr 1862:183408.

70. Cauna N (1980) Fine morphological characteristics and microtopography of the free nerve endings of the human digital skin. Anat Rec 198:643-656

71. Hilliges M, Wang L, Johansson O (1995) Ultrastructural evidence for nerve fibers within all vital layers of the human epidermis. J Invest Dermatol 104:134-137

72. Peier AM, Reeve AJ, Andersson DA, Moqrich A, Earley TJ, Hergarden AC, Story GM, Colley S, Hogenesch JB, McIntyre P, Bevan S, Patapoutian A (2002) A heat-sensitive TRP channel expressed in keratinocytes. Science 296(5575):2046-2049

73. Lumpkin EA (2007) Caterina MJ (2007) Mechanisms of sensory transduction in the skin. Nature 445:858-865

74. Julius D (2013) TRP channels and pain. Annu Rev Cell Dev Biol 29:355-384

75. Inoue K, Koizumi S, Fuziwara S et al (2002) Functional vanilloid receptors in cultured normal human epidermal keratinocytes. Biochem Biophys Res Commun 291:124-129

76. Pang Z, Sakamoto T, Tiwari V et al (2015) Selective keratinocyte stimulation is sufficient to evoke nociception in mice. Pain 156:656-665

77. Grando SA, Kist DA, Qi M, Dahl MV (1993) Human keratinocytes synthesize, secrete, and degrade acetylcholine. J Invest Dermatol 101:32-36

78. Koizumi S, Fujishita K, Inoue K, Shigemoto-Mogami Y, Tsuda $\mathrm{M}$, Inoue $\mathrm{K}$ (2004) $\mathrm{Ca}^{2+}$ waves in keratinocytes are transmitted to sensory neurons: the involvement of extracellular ATP and P2Y2 receptor activation. Biochem J 380:329-338

79. Zhao P, Barr TP, Hou Q et al (2008) Voltage-gated sodium channel expression in rat and human epidermal keratinocytes: evidence for a role in pain. Pain 139:90-105

80. Barr TP, Albrecht PJ, Hou Q et al (2013) Air-stimulated ATP release from keratinocytes occurs through connexin hemichannels. PLoS ONE 8:1-9

81. Kaur G, Singh N, Jaggi AS (2017) Mast cells in neuropathic pain: an increasing spectrum of their involvement in pathophysiology. Rev Neurosci 28:759-766

82. Skaper SD, Facci L, Zusso M, Giusti P (2017) Neuroinflammation, Mast Cells, and Glia: Dangerous Liaisons. Neuroscientist 23:478-498

83. Osipchuk Y, Cahalan M (1992) Cell-to-cell spread of calcium signals mediated by ATP receptors in mast cells. Nature 359(6392):241-244

84. Nakanishi M, Furuno T (2008) Molecular basis of neuroimmune interaction in an in vitro coculture approach. Cell Mol Immunol 5(4):249-259

85. Jakobsson PJ (2010) Pain: How macrophages mediate inflammatory pain via ATP signaling. Nat Rev Rheumatol 6:679-681

86. Kiguchi N, Kobayashi Y, Maeda T, Fukazawa Y, Tohya K, Kimura M, Kishioka S (2012) Epigenetic augmentation of the macrophage inflammatory protein $2 / \mathrm{C}-\mathrm{X}-\mathrm{C}$ chemokine receptor type 2 axis through histone $\mathrm{H} 3$ acetylation in injured peripheral nerves elicits neuropathic pain. J Pharmacol Exp Ther 340(3):577-587

87. Ristoiu V (2013) Contribution of macrophages to peripheral neuropathic pain pathogenesis. Life Sci 93:870-881
88. Raoof R, Willemen HLDM, Eijkelkamp N (2018) Divergent roles of immune cells and their mediators in pain. Rheumatol (United Kingdom) 57:429-440

89. Kobayashi Y, Kiguchi N, Fukazawa Y et al (2015) Macrophage-T cell interactions mediate neuropathic pain through the glucocorticoid-induced tumor necrosis factor ligand system. J Biol Chem 290:12603-12613

90. Shibata K, Sugawara T, Fujishita K, Shinozaki Y, Matsukawa $\mathrm{T}$, et al. (2011) The astrocyte-targeted therapy by bushi for the neuropathic pain in mice. PLoS ONE 6(8): e23510.

91. Nakagawa T, Kaneko S (2010) Spinal astrocytes as therapeutic targets for pathological pain. J Pharmacol Sci 114:347-353

92. Gao YJ, Ji RR (2010) Targeting astrocyte signaling for chronic pain. Neurotherapeutics 7:482-493

93. Cronin M, Anderson PN, Cook JE, Green CR, Becker DL (2008) Blocking connexin43 expression reduces inflammation and improves functional recovery after spinal cord injury. Mol Cell Neurosci 39:152-160

94. Huang C, Han X, Li X et al (2012) Critical role of connexin 43 in secondary expansion of traumatic spinal cord injury. J Neurosci 32:3333-3338

95. Ji RR, Donnelly CR, Nedergaard M (2019) Astrocytes in chronic pain and itch. Nat Rev Neurosci 20:667-685

96. Nam Y, Kim JH, Kim JH et al (2016) Reversible induction of pain hypersensitivity following optogenetic stimulation of spinal astrocytes. Cell Rep 17:3049-3061

97. Zhang J, Shi XQ, Echeverry S, Mogil JS, De Koninck Y, Rivest $S$ (2007) Expression of CCR2 in both resident and bone marrowderived microglia plays a critical role in neuropathic pain. J Neurosci 45:12396-12406

98. Rozanski GM, Li Q, Kim H, Stanley EF (2013) Purinergic transmission and transglial signaling between neuron somata in the dorsal root ganglion. Eur J Neurosci 37:359-365

99. Inoue K, Tsuda M (2009) Microglia and neuropathic pain. Glia 57:1469-1479

100. Tsuda M (2019) Microglia-mediated regulation of neuropathic pain: Molecular and cellular mechanisms. Biol Pharm Bull 42:1959-1968

101. Illes P (2020) P2X7 receptors amplify CNS damage in neurodegenerative diseases. Int J Mol Sci 21:1-31

102. Yegutkin GG (2014) Enzymes involved in metabolism of extracellular nucleotides and nucleosides: functional implications and measurement of activities. Crit Rev Biochem Mol Biol 49:473-497

103. Burnstock $G$ (2020) Introduction to purinergic signaling. Purinergic signaling: methods in molecular biology. New York, NY.

104. Huang B, Li X, Zhu XC, Lu YS (2014) Deceased expression of prostatic acid phosphatase in primary sensory neurons after peripheral nerve injury. Int J Clin Exp Pathol 7:8602-8608

105. Kan HW, Chang CH, Lin CL et al (2018) Downregulation of adenosine and adenosine $\mathrm{A} 1$ receptor contributes to neuropathic pain in resiniferatoxin neuropathy. Pain 159:1580-1591

106. Zylka MJ, Sowa NA, Taylor-Blake B, Twomey MA, Herrala A, Voikar V, Vihko P (2008) Prostatic acid phosphatase is an ectonucleotidase and suppresses pain by generating adenosine. Neuron 60(1):111-122

107. Sowa NA, Taylor-Blake B, Zylka MJ (2010) Ecto-5'-nucleotidase (CD73) inhibits nociception by hydrolyzing AMP to adenosine in nociceptive circuits. J Neurosci 30(6):2235-2244

108. Street SE, Walsh PL, Sowa NA et al (2011) PAP and NT5E inhibit nociceptive neurotransmission by rapidly hydrolyzing nucleotides to adenosine. Mol Pain 7:1-15

109. Dbouk HA, Mroue RM, El-Sabban ME, Talhouk RS (2009) Connexins: a myriad of functions extending beyond assembly of gap junction channels. Cell Commun Signal 7:1-17

110. Saez JC, Contreras JE, Bukauskas FF, Retamal MA, Bennett MV (2003) Gap junction hemichannels in astrocytes of the CNS. Acta Physiol Scand 179(1):9-22 
111. Isakson BE, Ramos SI, Duling BR (2007) $\mathrm{Ca}^{2+}$ and inositol 1,4,5-trisphosphate-mediated signaling across the myoendothelial junction. Circ Res 100(2):246-254

112. Retamal MA, Riquelme MA, Stehberg J, Alcayaga J (2017) Connexin43 hemichannels in satellite glial cells, can they influence sensory neuron activity? Front Mol Neurosci 10:1-9

113. Bruzzone S, Guida L, Zocchi E et al (2001) Connexin 43 hemichannels mediate $\mathrm{Ca}^{2+}$-regulated transmembrane $\mathrm{NAD}^{+}$ fluxes in intact cells. FASEB J 15:10-12

114. Stout CE, Costantin JL, Naus CCG, Charles AC (2002) Intercellular calcium signaling in astrocytes via ATP release through connexin hemichannels. J Biol Chem 277:10482-10488

115. Cherian PP, Siller-Jackson AJ, Gu S, Wang X, Bonewald LF, Sprague E, Jiang JX (2005) Mechanical strain opens connexin 43 hemichannels in osteocytes: a novel mechanism for the release of prostaglandin. Mol Biol Cell 16(7):3100-3106

116. Orellana JA, Froger N, Ezan P et al (2011) ATP and glutamate released via astroglial connexin 43 hemichannels mediate neuronal death through activation of pannexin 1 hemichannels. $\mathrm{J}$ Neurochem 118:826-840

117. Kang J, Kang N, Lovatt D et al (2008) Connexin 43 hemichannels are permeable to ATP. J Neurosci 28:4702-4711

118. Yin X, Feng L, Ma D et al (2018) Roles of astrocytic connexin-43, hemichannels, and gap junctions in oxygen-glucose deprivation/reperfusion injury induced neuroinflammation and the possible regulatory mechanisms of salvianolic acid B and carbenoxolone. J Neuroinflammation 15:1-24

119. Anselmi F, Hernandez VH, Crispino G et al (2008) ATP release through connexin hemichannels and gap junction transfer of second messengers propagate $\mathrm{Ca} 2+$ signals across the inner ear. Proc Natl Acad Sci U S A 105:18770-18775

120. Essenfelder GM, Bruzzone R, Lamartine J, Charollais A, Blanchet-Bardon C, Barbe MT, Meda P, Waksman G (2004) Connexin30 mutations responsible for hidrotic ectodermal dysplasia cause abnormal hemichannel activity. Hum Mol Genet 13(16): 1703-1714

121. Chen B, Xu H, Mi Y, Jiang W, Guo D, Zhang J, Zhao Y, Tang W (2020) Mechanisms of hearing loss and cell death in the cochlea of connexin mutant mice. Am J Physiol Cell Physiol 319(3):C569-C578

122. Kuang Y, Zorzi V, Buratto D et al (2020) A potent antagonist antibody targeting connexin hemichannels alleviates Clouston syndrome symptoms in mutant mice. EBioMedicine 57:1-13

123. Rash JE, Yasumura T, Davidson KGV et al (2001) Identification of cells expressing Cx43, Cx30, Cx26, Cx32 and Cx36 in gap junctions of rat brain and spinal cord. Cell Commun Adhes $8: 315-320$

124. Xing LY, Yang T, Sen CS, Chen G (2019) Connexin hemichannels in astrocytes: Role in CNS disorders. Front Mol Neurosci $12: 1-10$

125. Gajardo-Gómez R, Labra VC, Orellana JA (2016) Connexins and pannexins: New insights into microglial functions and dysfunctions. Front Mol Neurosci 9:1-19

126. Oviedo-Orta E, Evans WH (2004) Gap junctions and connexinmediated communication in the immune system. Biochim Biophys Acta - Biomembr 1662:102-112

127. Komiya H, Shimizu K, Ishii K et al (2018) Connexin 43 expression in satellite glial cells contributes to ectopic tooth-pulp pain. J Oral Sci 60:493-499

128. Manteniotis S, Lehmann R, Flegel C et al (2013) Comprehensive RNA-Seq expression analysis of sensory ganglia with a focus on ion channels and GPCRs in trigeminal ganglia. PLoS ONE $8: 1-30$

129. Hanani M, Spray DC (2020) Emerging importance of satellite glia in nervous system function and dysfunction. Nat Rev Neurosci 21:485-498
130. Panchina Y, Kelmanson I, Matz M et al (2000) A ubiquitous family of putative gap junction molecules [2]. Curr Biol 10:473-474

131. Dahl G, Keane RW (2012) Pannexin: from discovery to bedside in 11 4 years? Brain Res 1487:150-159

132. Sosinsky GE, Boassa D, Dermietzel R et al (2011) Pannexin channels are not gap junction hemichannels. Channels 5:37-41

133. Bruzzone R, Hormuzdi SG, Barbe MT, Herb A, Monyer H (2003) Pannexins, a family of gap junction proteins expressed in brain. Proc Natl Acad Sci U S A 100(23):13644-13649

134. Boassa D, Ambrosi C, Qiu F, Dahl G, Gaietta G, Sosinsky G (2007) Pannexin1 channels contain a glycosylation site that targets the hexamer to the plasma membrane. J Biol Chem 282(43):31733-31743

135. Dahl G (2015) ATP release through pannexon channels. Philos Trans R Soc B Biol Sci 370:1-11

136. Michalski K, Syrjanen JL, Henze E et al (2020) The cryo-EM structure of a pannexin 1 reveals unique motifs for ion selection and inhibition. Elife 9:1-14

137. Qu R, Dong L, Zhang J et al (2020) Cryo-EM structure of human heptameric Pannexin 1 channel. Cell Res 30:446-448

138. Ruan Z, Orozco IJ, Du J, Lü W (2020) Structures of human pannexin 1 reveal ion pathways and mechanism of gating. Nature 584(7822):646-651

139. Seminario-Vidal L, Okada SF, Sesma JI, Kreda SM, van Heusden CA, Zhu Y, Jones LC, O’Neal WK, Penuela S, Laird DW, Boucher RC, Lazarowski ER (2011) Rho signaling regulates pannexin 1-mediated ATP release from airway epithelia. J Biol Chem 286(30):26277-26286

140. Billaud M, Lohman AW, Straub AC, Looft-Wilson R, Johnstone SR, Araj CA, Best AK, Chekeni FB, Ravichandran KS, Penuela S, Laird DW, Isakson BE (2011) Pannexin1 regulates $\alpha 1$-adrenergic receptor- mediated vasoconstriction. Circ Res 109(1):80-85

141. Adamson SE, Meher AK, Chiu YH, Sandilos JK, Oberholtzer NP, Walker NN, Hargett SR, Seaman SA, Peirce-Cottler SM, Isakson BE, McNamara CA, Keller SR, Harris TE, Bayliss DA, Leitinger N (2015) Pannexin 1 is required for full activation of insulin-stimulated glucose uptake in adipocytes. Mol Metab 4(9):610-618

142 Velasquez S, Malik S, Lutz SE, Scemes E, Eugenin EA (2016) Pannexin 1 channels are required for chemokine-mediated migration of $\mathrm{CD} 4+\mathrm{T}$ lymphocytes: role in inflammation and experimental autoimmune encephalomyelitis. J Immunol 196(10):4338-47

143. Swayne LA, Boyce AKJ. Regulation of Pannexin 1 surface expression by extracellular ATP: potential implications for nervous system function in health and disease (2017) Front Cell Neurosci 11:230

144. Langlois S, Xiang X, Young K, Cowan BJ, Penuela S, Cowan KN Pannexin 1 and pannexin 3 channels regulate skeletal muscle myoblast proliferation and differentiation. J Biol Chem 289(44):30717-30731.

145. Zhang P, Ishikawa M, Doyle A, Nakamura T, He B, Yamada Y. Pannexin 3 regulates skin development via Epiprofin (2021) Sci Rep 11(1):1779.

146 Sanchez-Arias JC, Liu M, Choi CSW, Ebert SN, Brown CE, Swayne LA (2019) Pannexin 1 regulates network ensembles and dendritic spine development in cortical neurons. eNeuro 6(3):1-19

147. Penuela S, Harland L, Simek J, Laird DW (2014) Pannexin channels and their links to human disease. Biochem J 461(3):371-381

148. Zhang P, Ishikawa M, Doyle A et al (2021) Pannexin 3 regulates skin development via Epiprofin. Sci Rep 11:1779

149. Weilinger NL, Lohman AW, Rakai BD et al (2016) Metabotropic NMDA receptor signaling couples Src family kinases to pannexin-1 during excitotoxicity. Nat Neurosci 19:432-442 
150. Kirby BS, Sparks MA, Lazarowski ER et al (2021) Pannexin 1 channels control the hemodynamic response to hypoxia by regulating O2-sensitive extracellular ATP in blood. Am J Physiol - Hear Circ Physiol 320:H1055-H1065

151. Seo JH, Dalal MS, Calderon F, Contreras JE (2020) Myeloid Pannexin-1 mediates acute leukocyte infiltration and leads to worse outcomes after brain trauma. J Neuroinflammation $17: 1-13$

152. Mim C, Perkins G, Dahl G (2021) Structure versus function: are new conformations of pannexin 1 yet to be resolved? J Gen Physiol 153:1-17

153. Bao L, Locovei S, Dahl G (2004) Pannexin membrane channels are mechanosensitive conduits for ATP. FEBS Lett 572(1-3):65-68

154. Locovei S, Bao L, Dahl G (2006) Pannexin 1 in erythrocytes: Function without a gap. Proc Natl Acad Sci U S A 103:7655-7659

155. Chiu YH, Schappe MS, Desai BN, Bayliss DA (2018) Revisiting multimodal activation and channel properties of Pannexin 1. J Gen Physiol 150:19-39

156. Narahari AK, Kreutzberger AJ, Gaete PS, Chiu YH, Leonhardt SA, Medina CB, Jin X, Oleniacz PW, Kiessling V, Barrett PQ, Ravichandran KS, Yeager M, Contreras JE, Tamm LK, Bayliss DA (2021) ATP and large signaling metabolites flux through caspase-activated Pannexin 1 channels. Elife 7(10):e64787

157. Qu Y, Misaghi S, Newton K et al (2011) Pannexin-1 is required for ATP release during apoptosis but not for inflammasome activation. J Immunol 186:6553-6561

158. Suadicani SO, Iglesias R, Wang J, Dahl G, Spray DC, Scemes E (2012) ATP signaling is deficient in cultured Pannexin1-null mouse astrocytes. Glia 60(7):1106-1116

159. Onami K, Kimura $Y$, Ito $Y$ et al (2014) Nonmetal haptens induce ATP release from keratinocytes through opening of pannexin hemichannels by reactive oxygen species. J Invest Dermatol 134:1951-1960

160. Burma NE, Bonin RP, Leduc-Pessah H et al (2017) Blocking microglial pannexin-1 channels alleviates morphine withdrawal in rodents. Nat Med 23:355-360

161. Spray DC, Hanani M (2019) Gap junctions, pannexins and pain. Neurosci Lett 695:46-52

162. Harcha PA, López X, Sáez PJ et al (2019) Pannexin-1 channels are essential for mast cell degranulation triggered during type I hypersensitivity reactions. Front Immunol 10:2703

163. Chen MJ, Kress B, Han X et al (2012) Astrocytic CX43 hemichannels and gap junctions play a crucial role in development of chronic neuropathic pain following spinal cord injury. Glia 60:1660-1670

164. Procacci P, Magnaghi V, Pannese E (2008) Perineuronal satellite cells in mouse spinal ganglia express the gap junction protein connexin43 throughout life with decline in old age. Brain Res Bull 75:562-569

165. Chen G, Park CK, Xie RG et al (2014) Connexin-43 induces chemokine release from spinal cord astrocytes to maintain latephase neuropathic pain in mice. Brain 137:2193-2209

166. Spataro LE, Sloane EM, Milligan ED et al (2004) Spinal gap junctions: Potential involvement in pain facilitation. J Pain $5: 392-405$
167. Kim YS, Anderson M, Park K, Zheng Q, Agarwal A, Gong C, Saijilafu YL, He S, LaVinka PC, Zhou F, Bergles D, Hanani M, Guan Y, Spray DC, Dong X (2016) Coupled activation of primary sensory neurons contributes to chronic pain. Neuron 91(5):1085-1096

168. Ledda M, Blum E, De Palo S, Hanani M (2009) Augmentation in gap junction-mediated cell coupling in dorsal root ganglia following sciatic nerve neuritis in the mouse. Neurosci 164:1538-1545

169. Hanstein R, Zhao JB, Basak R, Smith DN, Zuckerman YY, Hanani M, Spray DC, Gulinello M (2010) Focal inflammation causes carbenoxolone-sensitive tactile hypersensitivity in mice. Open Pain J 3:123-133

170. Xu Q, Cheong YK, Yang F, Tiwari V, Li J, Liu J, Raja SN, Li W, Guan Y (2014) Intrathecal carbenoxolone inhibits neuropathic pain and spinal wide-dynamic range neuronal activity in rats after an L5 spinal nerve injury. Neurosci Lett 563:45-50

171. Bennett MVL, Contreras JE, Bukauskas FF, Sáez JC (2003) New roles for astrocytes: Gap junction hemichannels have something to communicate. Trends Neurosci 26:610-617

172. Evans WH, De Vuyst E, Leybaert L (2006) The gap junction cellular internet: Connexin hemichannels enter the signalling limelight. Biochem J 397:1-14

173. Scemes E, Giaume C (2006) Astrocyte calcium waves: what they are and what they do. Glia 54(7):716-725

174. Warwick RA, Hanani M (2013) The contribution of satellite glial cells to chemotherapy-induced neuropathic pain. Eur J Pain (United Kingdom) 17:571-580

175. Yoon SY, Robinson CR, Zhang H, Dougherty PM (2013) Spinal astrocyte gap junctions contribute to oxaliplatin-induced mechanical hypersensitivity. J Pain 14:205-214

176. Robinson CR, Dougherty PM (2015) Spinal astrocyte gap junction and glutamate transporter expression contributes to a rat model of bortezomib-induced peripheral neuropathy. Neurosci 285:1-10

177. Poulsen JN, Warwick R, Duroux M et al (2015) Oxaliplatin enhances gap junction-mediated coupling in cell cultures of mouse trigeminal ganglia. Exp Cell Res 336:94-99

178. Bond SR, Naus CC (2014) The pannexins: past and present. Front Physiol 1-24.

179. Hanstein R, Hanani M, Scemes E, Spray DC (2016) Glial pannexin 1 contributes to tactile hypersensitivity in a mouse model of orofacial pain. Sci Rep 6:1-10

180. Koyanagi S, Kusunose N, Taniguchi M et al (2016) Glucocorticoid regulation of ATP release from spinal astrocytes underlies diurnal exacerbation of neuropathic mechanical allodynia. Nat Commun 7:1-13

181. Zhang Y, Laumet G, Chen SR et al (2015) Pannexin-1 up-regulation in the dorsal root ganglion contributes to neuropathic pain development. J Biol Chem 290:14647-14655

182. Bravo D, Ibarra P, Retamal J et al (2014) Pannexin 1: A novel participant in neuropathic pain signaling in the rat spinal cord. Pain 155:2108-2115

183. Karatas H, Erdener SE, Gursoy-Ozdemir Y et al (2013) Spreading depression triggers headache by activating neuronal Panx 1 channels. Science 339:1092-1095

Publisher's note Springer Nature remains neutral with regard to jurisdictional claims in published maps and institutional affiliations. 